\title{
Studi Etnografi Tentang Bakat Di Kalangan Remaja Di Era Digital
}

\author{
${ }^{1}$ Abdul Hafez Assad, ${ }^{2}$ Resky Purnamasari Nasaruddin \\ Program Magister Antropologi, Universitas Hasanuddin Makassar ${ }^{1}$ \\ Program Studi Agama-agama, Institut Agama Kristen Negeri Toraja² \\ abdulhafezassad.unhas@outlook.com
}

\begin{abstract}
This article focuses on understanding talent and action in an effort to develop talent among teenagers in the digital era, which is important as now we are in digitalization era. This article is based on data collected through the application of observational techniques and in-depth interview techniques, both of which are typical in the application of ethnographic research methods, with the object of study 20 teenagers who live in Makassar City who were selected randomly. Applying the perspective of cognitive anthropology, the results of this study show; teenagers' understanding of talent as an important thing to be developed, especially in the fields of art, technology, and skills, which is carried out through self-taught learning by relying on information, both in the form of knowledge (including experience) and news, which is available on the internet and through various media applications. social. Talent is then understood as something that is formed and/or shaped through a learning process, and not as something that is given or has been present since birth, which if developed intensively can provide benefits for the owner, or has commercial value, because talent shows are part of what is supported in the community of digital era.
\end{abstract}

Keyword: talent, youth, learning, self-taught, digital age

\begin{abstract}
Abstrak: Artikel ini berfokus pada pemahaman tentang bakat dan tindakan untuk upaya menumbuhkembangkan bakat di kalangan remaja di era digital, yang mana hal tersebut menjadi penting sebab kini kita berada di era digitalisasi. Artikel ini berdasarkan data yang dikumpulkan melalui penerapan teknik pengamatan dan teknik wawancara mendalam, yang mana kedua teknik tersebut merupakan khas dalam penerapan metode penelitian etnografi, dengan obyek studi 20 remaja yang berdomisili di Kota Makassar yang dipilih secara acak. Menerapkan perspektif antropologi kognitif, hasil studi ini menunjukkan; pemahaman remaja tentang bakat sebagai suatu hal yang penting untuk ditumbuhkembangkan khususnya terkait bidang kesenian, teknologi, dan keterampilan, yang dilakukan melalui pembelajaran autodidak dengan mengandalkan informasi, baik berupa pengetahuan (termasuk pengalaman) maupun pemberitaan, yang tersedia di internet dan melalui ragam aplikasi media sosial. Bakat kemudian dipahami sebagai hal yang terbentuk dan/atau dibentuk melalui proses pembelajaran, dan bukan sebagai hal yang terberi atau telah terdapat sejak lahir, yang jika ditumbuhkembangkan secara intensif dapat memberikan keuntungan bagi pemiliknya, atau memiliki nilai komersial, sebab pertunjukan bakat menjadi bagian dari hal yang didukung di era digital.
\end{abstract}

Kata kunci: bakat, remaja, pembelajaran, autodidak, era digital

Article History: Received: 23-09-2021 Revised: 07-12-2021 Accepted: 09-12-2021




\section{Pendahuluan}

Bakat atau talenta, terbentuk dengan berawal pada ketertarikan seorang terhadap suatu atau beberapa hal yang dipahami dapat memberikan manfaat bagi diri, yang mana pada saat hal tersebut terjadi, terbentuk pula penilaian mengenai kemampuan diri dalam menguasai, melakukan, hingga menghasilkan, yang menjadi bagian dari keyakinannya ${ }^{1}$. Bakat memiliki kaitan erat dengan proses pembelajaran, sebab bakat bukanlah hal yang terberi, sebagaimana keberadaan emosi dalam diri manusia. Proses pembelajaran tersebut terjadi melalui beragam hal, yang mana kini, cara yang menjadi pilihan tunggal dalam upaya menumbuhkembangkan bakat ialah dengan menempatkan internet sebagai media utama pembelajaran, sebab sebagaimana kita ketahui, bahwa selain memuat beragam pengetahuan (termasuk pengalaman), internet juga memuat ragam informasi yang dibutuhkan lebih lanjut dalam upaya membentuk dan mengembangkan bakat.

Bakat, tentunya telah hadir sebelum internet menjadi fenomenal, atau bahkan sebelum smartphone menjadi media yang memudahkan kita mengakses pengetahuan serta informasi yang tersedia di internet. Pada tahun 1997, keberadaan bakat sebagai hal yang dipertunjukkan, telah dianggap sebagai salah satu dari fenomena sosial yang diistilahkan "war for talent", yang mana pertunjukan tersebut tidak hanya merujuk pada kemampuan yang dimiliki diri maupun kelompok melainkan pula pada tingkat negara ${ }^{2}$. Era digital sebagai era terjadinya peningkatan dan perluasan pengetahuan khususnya dalam konteks perekonomian dan kemasyarakatan ${ }^{3}$, telah menjadikan internet sebagai "panduan utama kehidupan" sehingga menjadi karakteristik, sebab tersedia beragam hal pada beragam website atau situs dengan penilaian penting atau tidak penting, baik maupun buruk, menjadi bagian dari pembaca atau yang menyaksikannya, dan telah digunakan secara masiv melalui beragam gawai yang pada itu terdapat beragam fitur. Dengan demikian, konteks kekinian menjadikan bakat sebagai fenomena sosial menjadi lebih nampak, sebagaimana yang dapat kita saksikan melalui tayangan pencarian bakat yang melibatkan negara dan benua seperti America Got Talent, British Got Talent, Asia Got Talent, dan lainnya. Melalui acara-acara pertunjukan bakat - meski acara-acara tersebut lebih dikenal sebagai ajang pencarian bakat - seorang yang telah memiliki ketertarikan berkenaan dengan apa yang dibaca atau disaksikannya dapat melanjutkan pada tingkatan selanjutnya, yaitu pembelajaran dengan tujuan yang tidak lain untuk menumbuhkembangkan bakatnya, yang oleh sebab itu, era digital diasumsikan sebagai

${ }^{1}$ David Ulrich, The Talent Trifecta, dalam Development and Learning in Organization, Vol. 22, No. 02, DOI: 10.1108/dlo.2008.08122bad.003, (Emerlad Publishing Limited, 2008); Ed Michaels, Helen Handfield-Jones, \& Beth Axelrod, The War for Talent, (Harvard Business School Press, 2001).

${ }^{2}$ Ed Michaels, Helen Handfield-Jones, \& Beth Axelrod, The War for Talent, (Harvard Business School Press, 2001); Schon Beechler \& Ian C. Woodward, The Global "War for Talent", dalam Journal of International Management, Vol. 15, DOI; 10.1016/j.intman.2009.01.002, (Elsevier Inc., 2009).

3Jill Shepherd, What is Digital Era?, dalam Georgios Doukidis, Nikolaos Mylonopoulus, \& Nancy Pouloudi, Social and Economic Transformation in the Digital Era, (IGI Global Publisher, 2004). 
era dimana upaya menumbuhkembangkan bakat menjadi lebih mudah dilakukan, bahkan tanpa bantuan orang lain untuk mengajarkannya. Hal ini menunjukkan bahwa bakat bukanlah suatu hal yang tidak penting untuk dikembangkan, sebab bakat kemudian dipahami sebagai hal yang merujuk pada kelebihan dan kekurangan, atau sebagai bagian dari kekuatan dan kelemahan, baik milik diri, kelompok, maupun sebagai bangsa. Hal ini juga menunjukkan bahwa bakat merupakan hal yang penting untuk dikaji secara ilmiah.

Studi mengenai bakat, lebih menekankan pada keberadaan dan fungsi bakat dalam konteks industri, yang dengan demikian menitikberatkan pada hasil dan manfaat yang akan dicapai melalui menumbuhkembangkan serta menerapkan bakat. Dalam studi tersebut, bakat dipahami berkaitan dengan keberadaan ambisi untuk sukses, abilitas dalam kepemimpinan, agilitas dalam memahami keadaan kekinian serta memprediksi masa depan, dan pencapaian pada masa yang akan datang ${ }^{4}$, yang terdapat dalam jiwa setiap orang namun masih belum diketahui tingkatannya sehingga perlu mengikuti pelatihan. Bakat kemudian dipandang sebagai hal yang dapat dikelola yang dimaksudkan serta bertujuan berkaitan dengan kepentingan perusahaan ${ }^{5}$. Akan tetapi, sebagaimana telah disinggung pada paragraf pertama, bakat bukanlah suatu hal yang terberi melainkan hal yang dipelajari, dan meski diawali dengan ketertarikan pada suatu atau beberapa hal, namun ketertarikan itu sendiri juga bukan suatu hal yang terberi melainkan bersumber dari pengetahuan. Proses pembelajaran yang dimaksud, kemudian membentuk budaya atau kebudayaan milik diri, kelompok, dan bangsa, sebab konsep ini merujuk pada aspek kognitif, tindakan, serta hasil dari penerapannya dalam kehidupan manusia 6 . Proses pembelajaran dengan tujuan menumbuhkembangkan bakat baik sebelum era digital maupun pada era digital, dapat berlangsung baik secara; autodidak atau belajar dengan cara menemukan berdasar ketertarikan, mempelajari atau memahami, serta mempraktekkan guna penguasaan secara sendiri tanpa bantuan orang lain, maupun; secara berkelompok yang terangkum dalam tiga kategori pendidikan, yaitu pendidikan formal, pendidikan informal, dan pendidikan non formal. Bakat sebagai hal yang tidak hanya dibentuk melainkan juga dikembangkan untuk

${ }^{4}$ David Ulrich \& Norm Smallwood, What is Talent?, dalam Leader to Leader, Vol. 2012, Isu 63, 5561, DOI; 10.1002/ltl.20011, (John Willey \& Sons, Inc., 2012).

${ }^{5}$ Carole Tansley, "What do we Mean by the Term 'Talent' in Talent Management", dalam Industrial and Commercial Training, Vol. 43, Isu 05, 226-274, DOI: 10.1108/00197851111145853, (Emerald Publishing Ltd., 2011); William A. Schiemann, From Talent Management to Talent Optimization, dalam Journal of World Business, Vol. 49, Isu 02, 281-288, (Elsevier Inc., 2013), DOI: 10.1016/j.jwb.2013.11.012; Betina Szkudlarek, Laurence Romani, Dan V. Caprar, \& Joyce S. Osland, The SAGE Handbook of CrossCultural Management, (SAGE Publication, Ltd., 2020).

${ }^{6}$ Mary Womack \& James G. III Duvall, Being Human; an Introduction to Cultural Anthropology, (Prentice Hall, 2001); Raymond Scupin \& Christopher R. DeCorse, Anthropology; a Global Perspective, (Prentice Hall, 2003); Michael Simonton, Introduction to Cultural Anthropology, (Kendall Hunt Publishing Company, 2014); Constantina Nadia Seremetakis, An Introduction to Cultural Anthropology, (Cambridge Scholar Publishing, 2017); Laura Tubelle de González, Nina Brown, \& Thomas Forsyth Mcilwraith (Editor), Perspectives; an Open Invitation to Cultural Anthropology, (American Anthropological Association, 2019). 
dipertunjukkan, menjadikan proses pembelajaran yang dilakukan tidak terbatas hanya pada cara-cara di dalam pembentukannya melainkan juga merujuk pada apa yang akan dilakukan setelahnya, apa hasil selanjutnya, dan termasuk perihal hal yang akan didapatkan setelahnya.

Studi ini menjadikan upaya remaja dalam menumbuhkembangkan bakat khususnya pada bidang kesenian, teknologi, dan keterampilan sebagai fokus. Ketiga bidang tersebut ditetapkan dengan berdasar asumsi, bahwa bakat berkaitan dengan ketiganya merupakan bakat fenomenal di era digital, yang mana asumsi ini terbentuk berdasar pengkajian yang kami lakukan pada pemberitaan di media massa, khususnya media eletronik, yang mana dipahami sebagai bakat yang fenomenal di era digital sebab ketiganya dapat dilanjutkan untuk tujuan komersialisasi. Atas dasar tersebut, hasil studi ini penting bagi para orang tua dan juga para pengajar, sebab dapat digunakan untuk pengembangan bakat anak atau peserta didik. Melalui fokus studi ini, ulasan tidak hanya kami arahkan pada proses pembelajaran guna upaya tersebut, namun juga mengulas mengenai faktor pendukung sehingga bakat pada ketiga bidang tersebut terwujud.

\section{Metode Penelitian}

Remaja, adalah salah satu kategori usia yang pada itu terdapat pembelajaran yang berbeda dengan kategori usia lainnya, sebab keadaan hidup yang mereka alami tentunya berbeda dengan yang dialami oleh kategori usia lainnya, yang oleh sebab itu kategori usia ini dipandang memiliki budaya atau kebudayaan yang khas, yang menjadi karakteristik mereka7. Berdasar hal ini, dengan demikian metode penelitian etnografi tepat untuk diterapkan dalam penelitian mengenai bakat di kalangan remaja di era digital, sebab metode ini secara khusus dimaksudkan dalam penelitian dimana terdapat pola-pola kebudayaan yang terbagi pada suatu kelompok kebudayaan ${ }^{8}$.

Suatu metode penelitian, memiliki kaidah yang dimaksudkan agar tujuan khususnya tercapai, yang dengan demikian, menerapkan metode penelitian etnografi berarti penerapan kaidah yang terdapat di dalamnya, yang mana merujuk pada kaidah dalam pengumpulan data, analisa data, dan penulisan karya tulis. Oleh sebab itu, dalam penelitian untuk artikel ini diterapkan; teknik pengamatan, sebagai teknik yang bertujuan agar etnografer (peneliti) memiliki pemahaman, atau yang diistilahkan pandangan emik, tentang situasi sosial yang pada itu terdapat aktor, peristiwa, dan tempat, dan; teknik wawancara mendalam, sebagai teknik yang bertujuan agar

${ }^{7}$ Mary Bucholtz, Youth and Cultural Practice, dalam Annual Review Anthropology, 31:525-552, (Annual Review of Anthropology, 2002); Doi: 10.1146/annurev.anthro.31.040402.085443; Dannie Kjeldgaard \& Søren Askegaard, The Glocalization of Youth Culture: The Global Youth Segment as Structures of Common Difference, dalam Journal of Consumer Research, 33:231-247, (Oxford Unversity Press, 2006), DOI: 10.1086/506304; Nancy J. Smith-Hefner, Youth Language, Gaul Sociability, and the New Indonesian Middle Class, dalam Jurnal Studi Pemuda, Vol. 1, No. 1, (Youth Studies Centre berkolaborasi dengan Faculty of Social and Political Sciences - Universitas Gadjah Mada, 2012).

8John W. Creswell, Qualitative Inquiry \& Research Design; Choosing among Five Approaches, (SAGE Publication Inc., 2007). 
etnografer dapat mengumpulkan data berkaitan dengan pemahaman 20 informan, atau yang diistilahkan pandangan etik ${ }^{9}$. Kedua teknik ini diterapkan kepada informan yang seluruhnya tergolong dalam kategori remaja, yang sedang bersekolah pada jenjang Sekolah Menengah Atas, yakni yang berusia antara 16 hingga 18 tahun, di Kota Makassar, yang diawali dengan pemilihan secara acak dan dilanjutkan dengan teknik snowball. Hasil penelitian, atau data yang telah dikumpulkan melalui kedua teknik tersebut selanjutnya dianalisa melalui penerapan teknik taksonomikal, yang adalah salah satu dari empat teknik analisa dalam metode penelitian etnografi, yang bertujuan untuk menemukan domain budaya ${ }^{10}$. Selain itu, dalam metode penelitian etnografi juga terdapat kaidah yang merujuk pada penulisan hasil penelitian, yang salah satu dari empat model penulisan etnografis ialah model penulisan etnografi tradisional, atau yang juga dikenal melalui istilah etnografi polos ${ }^{11}$, yang mana diterapkan dalam artikel ini.

\section{Hasil dan Pembahasan}

\section{Bakat sebagai Budaya Ekspresif hingga Komersialisasi Bakat}

Dalam disiplin antropologi sosial-budaya, budaya atau kebudayaan dipahami terdiri atas dua aspek, yaitu; aspek instrumen-kegunaan, yang merujuk pada fungsi kebudayaan dalam kehidupan, dan; aspek ekspresif, yang merujuk pada fungsi kebudayaan berkenaan dengan segala bentuk tindakan yang bertujuan untuk menghindari kewajiban-kewajiban dalam kehidupan ${ }^{12}$. Bakat, adalah wujud kebudayaan, yang jika diturunkan sebagai tindakan maka selanjutnya merujuk pada aspek ekspresif dari kebudayaan sebab bakat pada hakikatnya tidak dimaksudkan untuk hal yang bersifat serius, sebagaimana hobi. Namun demikian, pada konteks kekinian, atau tepatnya di era digital, bakat telah menjadi bagian dari kewajiban atau memiliki pengaruh pada kehidupan sebab di satu sisi telah dikategorikan sebagai profesi pekerjaan. YouTuber contohnya, sebelumnya merujuk pada bakat di bidang keterampilan dengan tipe tertentu, namun seiring perkembangannya, disebabkan komersialisasi jelas dapat memberikan keuntungan bagi pemilik bakat maka dianggap sebagai salah satu profesi yang hanya ditemukan di era digital. Hal ini menunjukkan perkembangan berupa perubahan dari wujud ekspresif kebudayaan menjadi kategori dalam aspek instrumen-kegunaan. Remaja yang menjadi obyek dalam studi ini, menunjukkan penilaian yang bersumber dari pemahaman mereka terkait bakat melalui

\footnotetext{
${ }^{9}$ Thomas N. Headland, Kenneth L. Pike, \& Marvin Harris (Editor), Emics and Etics; The Insider/Outsider Debate, (SAGE Publications, Inc., 1990).

${ }^{10}$ James P. Spradley, Participant Observation, (Holt, Reinhart \& Winston, 1979); James P. Spradley, The Ethnographic Interview, (Holt, Reinhart \& Winston, 1980).

${ }^{11}$ Michael Humphreys \& Tony Watson, Ethnographic Practices; from 'Writing-up Ethnographic Research' to 'Writing Ethnography', dalam Sierk Ybema, Dvora Yanow, Harry Wels, \& Frans Kamsteeg (Editor), Organizational Ethnography; Studying the Complexities of Everyday Life, (SAGE Publications, Inc., 2009:40-55).

${ }^{12}$ Garry Chick, Leisure and Culture; Issues for an Anthropology of Leisure, dalam Leisure Sciences, Vol. 20, 111-133, DOI: 10.1080/01490409809512269, (Taylor \& Francis, 1998).
} 
cara pandang yang dimaksud, yakni memandangnya sebagai hal yang memiliki nilai manfaat yang sangat tinggi.

\section{Kategori Bakat: Kesenian, Teknologi, dan Keterampilan}

Hasil penelitian yang kami lakukan, menunjukkan bahwa terdapat tiga kategori bakat yang menjadi ketertarikan di kalangan remaja, yang oleh sebab itu digandrungi. Ketiga kategori bakat tersebut, ialah bakat di bidang kesenian, teknologi, dan keterampilan.

\section{Bakat Di Bidang Kesenian}

Bakat sebagai suatu hal yang dipelajari dan oleh sebab itu terangkum dalam konsep budaya atau kebudayaan, yang mana, kebudayaan dipahami dalam aspek kegunaan untuk keberlangsungan kehidupan dan aspek ekspresif yang bertujuan untuk agar kehidupan tidak selamanya berlangsung dalam konteks formal. ${ }^{12}$ Aspek ekspresif tersebut merujuk pada kesenian, yang adalah konsep yang mencakup segala ekspresi terkait keindahan ${ }^{13}$, dimana imajinasi yang menjadi hal mendasar dari pembentukan karya seni dimaksudkan untuk menerangkan, memahami, dan menikmati hidup. ${ }^{14}$ Kesenian kemudian terdiri beberapa tipe, yang mana terkait dengan studi ini; seni musik dan seni kreasi adalah tipe yang dimaksud.

Pada tipe seni musik, olah vokal hingga memainkan alat musik adalah pilihan utama, yang mana hal ini bersumber dari pemahaman para remaja mengenai konsep bakat atau talenta, sebagaimana yang ditunjukkan melalui beragam acara pertunjukan bakat, atau yang lebih dikenal sebagai ajang pencarian bakat. Para remaja yang memiliki ketertarikan pada bakat ini kemudian mempertunjukkannya melalui media internet. Akan tetapi, tidak berarti bahwa mereka mengetahui cara dalam membaca partitur atau notasi, sebab yang menjadi penekanan bagi mereka ialah mendapatkan apresiasi dari keluarga, rekan-rekan, maupun pihak lainnya atas karya mereka yang terdengar indah. Menjadi penekanan bagi mereka ialah kemampuan yang dimiliki dalam olah vokal maupun memainkan alat musik. Pada tipe seni kreasi, sebenarnya lebih merujuk pada kreativitas yang berkaitan dengan seni tari, dimana dancing pada aplikasi-aplikasi live streaming menjadi cara dalam mempertunjukkan bakat mereka melalui media tersebut. Meski hal ini dapat dipahami sebagai kebiasaan yang mengikuti trend kekinian, namun pada hakikatnya suatu kebiasaan juga tidak terlepas dari adanya ketertarikan untuk melakukannya, yang mana ketertarikan itu kemudian ditunjukkan sebagai suatu bakat.

Kesenian sebagai hal yang merujuk keindahan sebenarnya tidak hanya terdiri atas kedua tipe tersebut. Namun di kalangan remaja di Kota Makassar, kedua tipe tersebut sebagai pilihan sebab lebih pada trend daripada mengolah bakat lainnya di

\footnotetext{
Utama, 1982)

${ }^{13}$ Koentjaraningrat, Kebudayaan Mentalitas dan Pembangunan, (Penerbit Gramedia Pustaka

${ }^{14}$ William A. Haviland, Antropologi, Jilid 2, (Penerbit Erlangga, 1993)
} 
bidang kesenian. Para remaja tersebut tidak tertarik pada tipe seni rupa, atau seni kreasi yang lebih kental dengan kesenirupaan, seperti membuat kreasi dengan menggunakan bahan dasar epoxy, atau memahat, mengukir, dan lainnya. Meski demikian, terdapat seni rupa, berupa kreasi dalam kaligrafi, yang meski juga merupakan atau menunjukkan keberadaan bakat namun kemudian dikategorikan sebagai hal yang merusak sebab memilih wadah fasilitas umum, atau yang diistilahkan vandalisme.

\section{Bakat Di Bidang Teknologi}

Teknologi bukanlah istilah untuk merujuk pada ilmu tentang teknik-teknik, dalam pengertian disiplin ilmu seperti antropologi, arkeologi, atau sosiologi. Teknologi merupakan konsep yang dipahami sebagaimana pengertian teknik itu sendiri, yaitu suatu atau beberapa aksi yang efektif, ${ }^{15}$ sehingga teknologi merujuk pada sejumlah teknik atau aksi yang telah diketahui efektif untuk diterapkan pada konteks tertentu. Namun tentunya bermain game atau permainan digital tidak termasuk dalam kategori teknologi, sebab teknik yang diterapkan lebih merujuk pada strategi, sebagaimana strategi dalam permainan sepak bola atau olah raga lainnya, atau dalam strategi berkaitan dengan bertahan hidup di lingkungan yang tidak menjadi habitat umum. Teknik yang dimaksud merujuk pada tujuan penyelesaian ragam masalah dalam teknologi itu sendiri, atau material dari teknologi, atau alat dimana teknik melekat, terutama teknik yang berkaitan dengan kerusakan dan pengembangan peralatan.

Teknik terkait kerusakan dan pengembangan peralatan, merujuk pada bakat dalam bidang teknologi, dimana memperbaiki, merakit, dan meretas peralatan menjadi pilihan. Meski bakat ini memerlukan proses pembelajaran yang tidak mudah, namun tidak berarti bahwa seorang yang tertarik harus memiliki ilmu pengetahuan dasar yang selanjutnya menjadi pendukung dalam proses pembelajaran audio-visual interet, sebab bakat ini, di satu sisi, memerlukan ketekunan dalam menganalisa cara-cara dan kesalahan-kesalahan, selain juga mengenai penguasaan peralatan itu sendiri. Sebagaimana konteks memperbaiki kendaraan, baik bermotor maupun tidak bermotor, saat ini dapat dilakukan dengan mempelajarinya melalui internet, dengan catatan bahwa seorang yang dimaksud benar memiliki ketertarikan pada hal tersebut, meski sama sekali tidak memiliki pengetahuan dasar-sebab jika seorang memiliki pengetahuan dasar, seperti telah mendapat pendidikan di Sekolah Teknik Menengah, justru berharap untuk bekerja pada perbengkelan milik suatu perusahaan automotif. Bakat ini menjadikan beberapa remaja kemudian membuka usaha di bidang perbaikan smartphone dan laptop. Selain itu, beberapa remaja juga menjadikan bakat ini untuk mendalami dunia internet, yang meski menjadi peretas, namun tidak semua peretas dapat dikategorikan buruk sebab terdapat pengelompokan.

${ }^{15}$ Marcel Mauss, Sociologie et Anthropologie, (Presses Universitaries de France, 1983) 


\section{Bakat Di Bidang Keterampilan}

Dalam bahasa Indonesia, bakat atau talenta, sering pula diistilahkan keterampilan, sebab seorang yang memiliki bakat dan ditunjukkan untuk tujuan tertentu berarti memiliki keterampilan. Akan tetapi, keterampilan itu sendiri adalah istilah yang terpisah dari bakat, sebab meski keduanya tumbuh dan berkembang melalui proses pembelajaran namun keterampilan memiliki pendidikan yang lebih teratur daripada bakat. Hal ini dapat dipahami melalui tipe bakat yang juga berarti tipe keterampilan, seperti pada tipe bakat atau keterampilan; jahit-menjahit, adalah suatu hal yang jika dipelajari melalui pembelajaran intensif yang disebut pendidikan informal, maka hal tersebut lebih dapat dipahami sebagai keterampilan, sedangkan ketertarikan awal pada hal tersebut jelas menunjukkan keberadaan bakat dalam diri, yang tanpa proses pembelajaran yang intensif melalui tipe pendidikan informal, yakni dipelajari secara autodidak, maka selanjutnya juga dapat dipahami sebagai keterampilan. Dengan kata lain, istilah bakat dan keterampilan adalah dua hal yang berada dalam satu pengertian, namun dapat dibedakan melalui proses pembelajaran yang dilakukan untuk menumbuhkembangkan salah satunya. Berdasar hal ini, bakat yang terkait dengan keterampilan dalam artikel ini, dengan demikian, adalah bakat yang ditumbuhkembangkan melalui proses pembelajaran secara autodidak.

Ketertarikan para remaja terkait bakat dalam bidang keterampilan, ditujukan pada keterampilan berkenaan dengan masak-memasak, yang mana hal ini tentunya merujuk pada ketertarikan para informan untuk artikel ini. Bakat ini muncul karena adanya kebiasaan masak-memasak sebelumnya, yang kemudian didukung dengan informasi mengenai jenis makanan (termasuk minuman) tertentu yang sedang menjadi topik dalam pembicaraan publik, dan juga menjadi komoditi dalam bisnis kuliner. Bakat ini kemudian ditumbuhkembangkan secara autodidak, dengan menjual produk diawali dengan kemasan kecil untuk konsumen orang disekitar mereka, yang selanjutnya berkembang dengan memahami penilaian atas produk mereka. Upaya menumbuhkembangkan bakat kemudian berlanjut dengan menjual komoditi mereka melalui media sosial.

\section{Menumbuhkembangkan Bakat di Era Digital}

Meski sebelumnya telah dijelaskan bahwa para remaja menilai bakat sebagai suatu hal yang sangat penting untuk ditumbuhkembangkan, namun tidak berarti bahwa keseluruhan remaja berhasil dalam menumbuhkembangkan bakat mereka, sebab untuk menumbuhkembangkan bakat diperlukan proses pembelajaran secara intensif. Bakat, tidak dapat dipahami sebagai suatu hal yang terberi, atau telah terdapat dalam diri sejak lahir, sehingga tidak dapat dibandingkan keberadaan perasaan dalam jiwa. Bakat, merupakan hal yang di(ter)bentuk melalui proses pembelajaran, yang mana di dalam proses tersebut seorang akan menghadapi tantangan berupa ketidaksamaan antara harapan dan keinginan, sebab apa yang dipikirkan saat melihat suatu hal dan telah 
menjadi gambaran ideal dalam benak sangat dapat berbeda dengan kenyataan, saat pikiran tersebut diubah menjadi tindakan atau material. Dengan kata lain, jika proses pembelajaran terkait perasaan dalam jiwa hanya sebatas melabelkan atau mengistilahkan - sebagaimana perasaan atas suatu hal yang menyebabkan air mata mengalir meski tanpa isak tangis dilabelkan atau diistilahkan sebagai perasaan sedih maka proses pembelajaran untuk menumbuhkembangkan bakat melibatkan pikiran, tindakan, dan mental berupa tekad dan/atau keteguhan yang kuat selain juga ketekunan dan sikap siap menerima hasil karya sendiri. Selain persoalan ketidaksamaan antara harapan dan keinginan, proses pembelajaran untuk menumbuhkembangkan bakat juga memiliki tantangan lain, yakni ketiadaan mentor dalam kehidupan nyata, dan jika terdapat mentor maka seakan-akan informasi di internet yang berkaitan dengan bakat tidak berguna. Oleh sebab itu, upaya dalam menumbuhkembangkan bakat memerlukan pikiran, tindakan, dan mental, sebab meski tidak berarti bahwa seluruh "pelajar" melakukannya namun pada umumnya, proses pembelajaran terkait upaya menumbuhkembangkan bakat berlangsung secara autodidak. Mungkin saja, hal ini yang selanjutnya membentuk pandangan bahwa "bakat itu bawaan" yang berarti terberi, atau sebagai karunia Ilahiyah.

Bagi para remaja yang telah menganggap dirinya berhasil menumbuhkembangkan bakatnya, dan juga telah mendapat pengakuan dari keluarga dan/atau rekan-rekannya, menilai upaya menumbuhkembangkan bakat di era digital sebagai hal yang mudah, sebab pada internet dan media sosial terdapat ragam informasi baik berupa pengetahuan (termasuk pengalaman) seseorang maupun pemberitaan terkait suatu bakat, yang dinilai sebagai sumber daya guna menumbuhkembangkan bakat. Sumber daya tersebut merujuk pada ketersediaan informasi; tentang cara dan/atau strategi, berkaitan dengan material, dan berkaitan dengan komersialisasi bakat.

\section{Ketersediaan Informasi tentang Cara dan Strategi}

Ketiga kategori bakat yang telah diulas sebelumnya, menjadi pilihan para remaja sebab mendapat dukungan di internet dan di media sosial, yang mana dukungan tersebut berupa informasi mengenai cara dan/atau strategi. Yang dimaksud cara, merujuk pada penggunaan dan/atau penerapan dasar suatu hal hingga tingkat profesional (basic to advance), sedangkan yang dimaksud strategi, merujuk pada trik dengan tujuan beragam. Pada kategori kesenian, dukungan mengenai cara dan/atau strategi merujuk pada penggunaan alat musik, atau material pendukungnya. Pada kategori teknologi, dukungan mengenai cara dan/atau strategi nampak dalam komunitas-komunitas baik yang berasal dari dalam maupun luar negeri. Hal ini lebih banyak terjadi pada bakat bidang teknologi berkaitan dengan teknik komputerisasi terutama dalam perbaikan dan pengembangan. Pada kategori keterampilan, dukungan 
cara dan/atau strategi merujuk pada penggunaan peralatan utama dan peralatan bantu berkaitan dengan bakat.

\section{Ketersediaan Informasi Berkenaan dengan Material}

Tidak dapat dipungkiri bahwa bakat yang menjadi pilihan para remaja, yakni yang terangkum dalam kategori kesenian, teknologi, dan keterampilan, membutuhkan material utama dan tambahan agar realisasi dari bakat terwujud. Dalam konteks artikel ini, bakat pada bidang; kesenian, jelas membutuhkan microphone untuk mengolah vokal dan beragam alat musik utamanya gitar dalam menumbuhkembangkan bakat musikal; teknologi, dibutuhkan smartphone, laptop, atau peralatan elektronika lainnya untuk menumbuhkembangkan bakat memperbaiki dan mengembangkan teknologi, dan; kesenian, membutuhkan peralatan masak dan juga material untuk membuat dan/atau mendukung masakan. Meski tanpa material yang dimiliki secara pribadi bakat-bakat tersebut tetaplah dapat ditumbuhkembangkan namun material tersebut tidak dapat dianggap sebagai pendukung, dan juga tidak dapat dianggap sebagai utama, sebab proses pembelajaran autodidak umumnya mengandalkan material yang telah ada disekeliling, dan material tersebut akan menjadi utama saat bakat dalam perjalanan menuju atau telah mencapai tingkat profesionalitas. Informasi rinci atau detail mengenai ragam material utama atau pendukung yang dimaksud, tersedia di internet dan media sosial, yang mana merujuk pada besaran harga, spesifikasi material, lokasi pembelian material, kelebihan dan kekurangan suatu produk material, yang selanjutnya menjadi panduan dalam pemilihan dan penggunaan atau penerapan, untuk tujuan menumbuhkembangkan bakat.

\section{Ketersediaan Informasi Berkaitan dengan Komersialisasi Bakat}

Komersialisasi di era digital, tidak hanya merujuk pada komersialisasi suatu produk di dunia nyata, dimana seorang menjual komoditinya kepada calon atau para konsumen, yang selanjutnya terjadi tawar-menawar dalam aktivitas transaksi. Komersialisasi di era digital dapat berupa penjualan sebagai di dunia nyata namun tanpa tawar-menawar, dan dapat berupa monetisasi produk dengan melekatkan periklanan tertentu, yang selanjutnya memberikan keuntungan. Khususnya bentuk komersialisasi kedua, menjadi pilihan dalam komersialisasi bakat, yang dipertunjukkan melalui aplikasi, baik aplikasi berbasis website - seperti Youtube atau Instagram maupun aplikasi tidak berbasis website - seperti TikTok atau aplikasi live streaming lainnya. Informasi berupa pengetahuan (termasuk pengalaman) yang berkaitan dengan komersialisasi bakat, dapat dengan mudah didapatkan melalui chat atau membaca chat, atau melalui informasi berupa pemberitaan. Informasi tersebut kemudian yang ditanggapi sebagai sumber daya dalam menunjung upaya menumbuhkembangkan bakat disemua bidang. 


\section{Kesimpulan}

Bakat dipahami sebagai hal yang terbentuk dan/atau dibentuk melalui proses pembelajaran, dan bukan sebagai hal yang terberi atau telah terdapat sejak lahir, yang jika ditumbuhkembangkan secara intensif dapat memberikan keuntungan bagi pemiliknya, sebab pertunjukan bakat menjadi bagian dari hal yang didukung di era digital. Bakat yang menjadi pilihan di kalangan remaja ialah bakat yang berkaitan dengan bidang kesenian, dimana seni musik dan seni kreasi terkait seni tari. Teknologi, dimana teknik memperbaiki dan mengembangkan teknologi serta keterampilan yaitu terampil dalam hal masak-memasak. Bakat pilihan tersebut kemudian ditumbuhkembangkan sebab menjadi bagian dari dukungan internet, berkaitan dengan ketersediaan informasi cara dan/atau strategi, ketersediaan informasi berkenaan dengan material, dan ketersediaan informasi berkaitan dengan komersialisasi bakat.

\section{Referensi}

Beechler, Schon., \& Woodward, Ian C. 2009. The Global "War for Talent". Dalam Journal of International Management, Vol. 15, DOI: 10.1016/j.intman.2009.01.002, Elsevier Inc.

Bucholtz, Mary. 2002. Youth and Cultural Practice. Dalam Annual Review Anthropology, 31:525-552, Annual Review of Anthropology. DOI:

10.1146/annurev.anthro.31.040402.085443.

Chick, Garry. 1998. Leisure and Culture; Issues for an Anthropology of Leisure. Dalam Leisure Sciences, Vol. 20, 111-133, Taylor \& Francis. DOI: 10.1080/01490409809512269.

Creswell, John W. 2007. Qualitative Inquiry \& Research Design; Choosing among Five Approaches. SAGE Publication Inc.

González, Laura Tubelle de., Brown, Nina., \& Mcilwraith, Thomas Forsyth (Editor). 2019. Perspectives; an Open Invitation to Cultural Anthropology. American Anthropological Association.

Haviland, William A. 1993. Antropologi, Jilid 2, Penerbit Erlangga

Headland, Thomas N., Pike, Kenneth L., \& Harris, Marvin (Editor). 1990. Emics and Etics; The Insider/Outsider Debate. SAGE Publications, Inc.

Humphreys, Michael., \& Watson, Tony. Ethnographic Practices; from 'Writing-up Ethnographic Research' to 'Writing Ethnography'. Dalam Sierk Ybema, Dvora Yanow, Harry Wels, \& Frans Kamsteeg (Editor), 2009, Organizational Ethnography; Studying the Complexities of Everyday Life, 40-55, SAGE Publications, Inc.

Kjeldgaard, Dannie. \& Askegaard, Søren. 2006. The Glocalization of Youth Culture: The Global Youth Segment as Structures of Common Difference. Dalam Journal of Consumer Research, 33:231-247, Oxford Unversity Press. DOI: 10.1086/506304. 
Koentjaraningrat. 1982. Kebudayaan Mentalitas dan Pembangunan. Penerbit Gramedia Pustaka Utama.

Michaels, Ed., Handfield-Jones, Helen., \& Axelrod, Beth. 2001. The War for Talent. Harvard Business School Press.

Shepherd, Jill. 2004. What is Digital Era? Dalam Georgios Doukidis, Nikolaos Mylonopoulus, \& Nancy Pouloudi, Social and Economic Transformation in the Digital Era, IGI Global Publisher.

Spradley, James P. 1979. Participant Observation. Holt, Reinhart \& Winston 1980. The Ethnographic Interview. Holt, Reinhart \& Winston

Mauss, Marcel. 1983. Sociologie et Anthropologie. Presses Universitaries de France

Ulrich, David. 2008. The Talent Trifecta. Dalam Development and Learning in Organization, Vol. 22, No. 02, Emerlad Publishing Limited. DOI: 10.1108/dlo.2008.08122bad.003.

Tansley, Carole. 2011. "What do we Mean by the Term 'Talent' in Talent Management". Dalam Industrial and Commercial Training, Vol. 43, Isu 05, 226-274, Emerald Publishing Ltd. DOI: 10.1108/00197851111145853.

Schiemann, William A. 2013. From Talent Management to Talent Optimization. Dalam Journal of World Business, Vol. 49, Isu 02, 281-288, Elsevier Inc. DOI: 10.1016/j.jwb.2013.11.012.

Scupin, Raymond. \& DeCorse, Christopher R. 2003. Anthropology; a Global Perspective. Prentice Hall.

Seremetakis., Constantina Nadia. 2017. An Introduction to Cultural Anthropology. Cambridge Scholar Publishing.

Simonton, Michael. 2014. Introduction to Cultural Anthropology. Kendall Hunt Publishing Company.

Smith-Hefner, Nancy J. 2012. Youth Language, Gaul Sociability, and the New Indonesian Middle Class. Dalam Jurnal Studi Pemuda, Vol. 1, No. 1, Youth Studies Centre berkolaborasi dengan Faculty of Social and Political Sciences - Universitas Gadjah Mada.

Szkudlarek, Betina., Romani, Laurence., Caprar, Dan V., \& Osland, Joyce S. 2020. The SAGE Handbook of Cross-Cultural Management. SAGE Publication, Ltd.

Womack, Mary. \& Duvall, James G. III. 2001. Being Human; an Introduction to Cultural Anthropology. Prentice Hall. 